Check for updates

Cite this: Chem. Sci., 2018, 9, 2365

\title{
Chemical synthesis of membrane proteins: a model study on the influenza virus $B$ proton channel $\uparrow$
}

\begin{abstract}
A. C. Baumruck, ${ }^{a}$ D. Tietze, (DD ${ }^{b}$ L. K. Steinacker ${ }^{a}$ and A. A. Tietze (iD *a
In the present study we have developed and optimized a robust strategy for the synthesis of highly hydrophobic peptides, especially membrane proteins, exemplarily using the influenza B M2 proton channel (BM2(1-51)). This strategy is based on the native chemical ligation of two fragments, where the thioester fragment is formed from an oxo-ester peptide, which is synthesized using Fmoc-SPPS, and features an in situ cleavable solubilizing tag $\left(\mathrm{ADO}, \mathrm{ADO}_{2}\right.$ or $\left.\mathrm{ADO}-\mathrm{Lys}_{5}\right)$. The nearly quantitative production of the ligation product was followed by an optimized work up protocol, resulting in almost quantitative desulfurization and Acm-group cleavage. Circular dichroism analysis in a POPC lipid membrane revealed that the synthetic BM2(1-51) construct adopts a helical structure similar to that of the previously characterized BM2(1-33).
\end{abstract}

Received 1st January 2018

Accepted 21st January 2018

DOI: $10.1039 / \mathrm{c} 8 \mathrm{sc} 00004 \mathrm{~b}$

rsc.li/chemical-science

fragments by chemical synthesis might be even more important with respect to the development of bio-inspired materials. ${ }^{8}$

The syntheses of highly hydrophobic peptides are usually performed using specifically optimized synthetic strategies.,10 Peptides with more than 50 amino acids in length are usually obtained by fusing two or several peptide fragments through native chemical ligation (NCL). ${ }^{11-14}$ The work up, including purification steps, for those peptides is usually challenging, since these peptides contain a high number of amino acids with hydrophobic side chains, which causes their aggregation in conventional solvents. ${ }^{7,15}$ The first attempt of the synthesis of influenza A virus M2 membrane protein was performed by Kochendoerfer et al. The authors used a Boc-based SPPS, and for the ligation step they used $6 \mathrm{M}$ guanidinium chloride containing $20 \%$ TFE in order to solubilize the peptide, resulting in $65 \%$ product formation. ${ }^{12}$

Various methods have been established to overcome difficulties in the chemical synthesis of highly hydrophobic peptides, and they mainly focus on increasing the coupling efficiency ${ }^{16}$ by improving the protocols of Fmoc-based solid phase peptide synthesis (SPPS). ${ }^{17,18}$ The incorporation of pseudo-prolines was designed in order to reduce the aggregation during the chain prolongation by Fmoc-based SPPS, while at the same time being easily acid-cleavable. ${ }^{19,20}$ Alternatively, the incorporation of depsipeptide or $O$-acyl isopeptide units has been used to increase the solubility of hydrophobic peptides. ${ }^{20,21}$ However, even using these improved synthetic methods, purification remains extremely challenging. Aside from employing various mixtures of organic solvents ${ }^{18,22-24}$ and/ or $\mathrm{C} 4, \mathrm{C} 1$ or phenyl columns ${ }^{18,24,25}$ for the HPLC purification of such peptides, the use of removable modifications, ${ }^{26-32}$ which can be incorporated to the peptide/protein's C- or N-terminus or backbone, was demonstrated to partly overcome the problem of

${ }^{a}$ Darmstadt University of Technology, Clemens-Schöpf Institute of Organic Chemistry and Biochemistry, Alarich-Weiss Str. 4, 64287 Darmstadt, Germany. E-mail: a. tietze@tietze-lab.de

${ }^{b}$ Darmstadt University of Technology, Eduard-Zintl-Institute of Inorganic and Physical Chemistry, Alarich-Weiss-Str. 4, 64287 Darmstadt, Germany

$\dagger$ Electronic supplementary information (ESI) available. See DOI: $10.1039 / \mathrm{c} 8 \mathrm{sc} 00004 \mathrm{~b}$ 
handling hydrophobic peptides during their production. Therefore, positively charged amino acids, such as polyarginines or polylysines, were employed in order to increase the solubility of hydrophobic peptides. ${ }^{33-38}$ However, these solubilizing tags are usually not removable and they alter the native sequence of the target peptide, which might impair peptide functionality. Consequently, removable solubilizing tags were developed which attach to the peptide via a cleavable linker (e.g. 4-hydroxymethyl benzoic acid (4-Hmb), 3,4-diaminobenzoic acid (Dbz) or 4-methoxy-5-nitrosalicylaldehyde), ${ }^{30,39}$ an amino acid side chain/backbone, ${ }^{28,29,40}$ or a short peptidase recognition site (which can be cleaved after the acidic residues using carboxypeptidase B)..$^{36,39,41,42}$ Nevertheless, only a few examples of cleavable solubilizing tags for chemical synthesis are described to date (Table $\mathrm{S} 1 \dagger$ ).

Considering the NCL mechanism, the addition of solubilizing tags on the thioester-leaving group might be another promising strategy to increase the solubility of hydrophobic peptides, since the solubilizing tag is removed during the process of ligation, retaining the native peptide sequence. In 2007, Johnson et al. incorporated a polyarginine (Arg6) solubilizing tag attached to a thioester-leaving group using a Bocbased peptide synthesis protocol (Table S1†). ${ }^{33}$ Most of the examples described in the literature for the synthesis of membrane proteins and their parts were by Boc-SPPS (Table $\mathrm{S} 1 \dagger$ ), which usually requires special equipment, due to the use of $\mathrm{HF}$ in the final global deprotection and cleavage from the resin used in SPPS. ${ }^{\mathbf{4 3 4 4}}$ Although, some Fmoc-based methods using peptide hydrazides were applied for membrane protein synthesis. ${ }^{13,45}$ However, incorporation of a C-terminal solubilizing tag into peptide hydrazides is problematic. Therefore, a solution for this problem had to be found.

About a decade ago, an interesting Fmoc-SPPS compatible oxoester-based NCL strategy was described, which relied on the in situ generation of the thioester through an $O$-to- $S$ acyl shift of the 2-hydroxy-3-mercaptopropionic acid (Hmp) moiety, which then reacts with the Cys-fragment to generate the final ligation product. ${ }^{46-48}$ Using this method, small glycopeptides,${ }^{47}$ the NNYRantes polypeptide chain (comprising residues $1-68),{ }^{49}$ and cyclotides $^{50}$ have been synthesized. However, under standard NCL conditions, high amounts $(20-25 \%)$ of the hydrolyzed $\mathrm{C} \alpha$ carboxyester by-product were reported. ${ }^{\mathbf{4 9 , 5 1}}$ Moreover, the Hmp unit was found to be labile during standard Fmoc-SPPS, which might explain why this elegant strategy has not found a wide use. In 2013, Liu et al. observed that the use of 2-methylpiperidine instead of piperidine for the Fmoc-deprotection step nicely solved the instability problem during the Fmoc-SPPS of peptide-oxoesters. ${ }^{51}$

At this point, we realized that this strategy can be employed to introduce solubilizing tags during Fmoc-SPPS that can be easily cleaved in a one-step reaction during the NCL procedure, resulting in a significant improvement of the NCL of highly hydrophobic protein fragments. Consequently, the thioesterforming Hmp unit would serve as a cleavable linker between the solubilizing tag and the peptide chain.

Thus, our strategy combines the ligation of a conventional Cys-peptide fragment to an N-terminal fragment, which carries a removable, thioester-forming Hmp unit followed by a short PEG linker and a solubilizing tag. To demonstrate the feasibility of our anticipated strategy, we sought to synthesize small model peptides and an extended part of the membrane region of the influenza B proton channel (BM2), which is a highly hydrophobic peptide and is prototypical for the class of small membrane-spanning ion channels. Moreover, BM2 represents an important drug target for the treatment of seasonal flu, and its molecular structure has not been fully solved yet. ${ }^{52-55}$ An efficient synthesis of such ion channel-forming peptides is of high importance, especially to the NMR community and their need for isotopically labelled samples.

\section{Results and discussion}

\section{Development and optimization of the synthesis and NCL protocol for the Hmp unit using model peptides}

In order to optimize the synthetic strategy for the Hmp-peptide fragments (the thioester-forming peptide), a set of four different model peptides (1-4) was employed and ligated to a small Cyspeptide fragment (5) (Table S2 and S3, $\dagger$ and Fig. 1). The sequences of these peptides were derived from the influenza virus BM2 protein sequence (Fig. 1a, Table S2 $\dagger$ ), comprising residues 17 to 21 for the Hmp-peptide and residues 22 to 35 for the Cys-peptide fragment.

As described above, the Hmp unit was attached to a polylysine and/or mini-PEG solubilizing tag and incorporated into the model peptide fragments 1-4. More precisely, the thioesterforming peptides 2-4 were composed of four consecutive units: the peptide sequence, the Hmp unit, ${ }^{\mathbf{4 9 , 5 1}}$ a spacer (if necessary), and the solubilizing tag (Fig. 1b). Peptide 1 did not contain any solubilizing tag and/or spacer, and was used as a reference. During the NCL reaction, the Hmp unit forms the required intermediate thioester through an intermolecular $S$ to $O$-acyl transfer, which is then followed by cleavage of the solubilizing tag upon formation of the MPAA thioester (Fig. 1b). Prior to the synthesis of the model peptides 1-4, the Hmp unit was synthesized as a racemic mixture according to the procedure described by K. Wisniewski. ${ }^{56}$ The Hmp racemic mixture was directly used for Fmoc-SPPS, leading to a peptide mixture containing diastereomer $\mathrm{A}$ and diastereomer $\mathrm{B}$ which eluted in HPLC chromatograms at different retention times.

In the first attempt, the native BM2 sequence comprising residues 17 to 21 (ALHFI, Fig. S3a, b†) was coupled to the Hmp unit, resulting in a very low ligation yield and a high degree of carboxyester hydrolysis (90\%) (Fig. S1c $\dagger$ ). This result was caused by the poor $S$ to $O$-acyl shift yields when isoleucine (Ile21) is the C-terminal amino acid, as reported by Liu et al. ${ }^{51}$ Therefore, Ile21 was mutated to Leu21, which did not show such a high degree of carboxyester hydrolysis. ${ }^{51}$ Moreover, Ala22 was chosen as the respective ligation point, and was thus changed to Cys22 (Fig. 1a).

Polylysine $\left(\mathrm{Lys}_{5}\right)^{57,58}$ or one or two 8-amino-(ADO) units were tested as solubilizing tags. ${ }^{59}$ Additionally, ADO was used as a spacer in combination with the $\mathrm{Lys}_{5}$ tag, in order to reduce any steric hindrance arising from the lysine Boc-protecting groups during the Hmp coupling (Table S2 $\dagger$ ). 


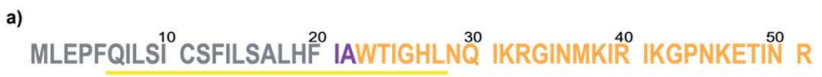

b)

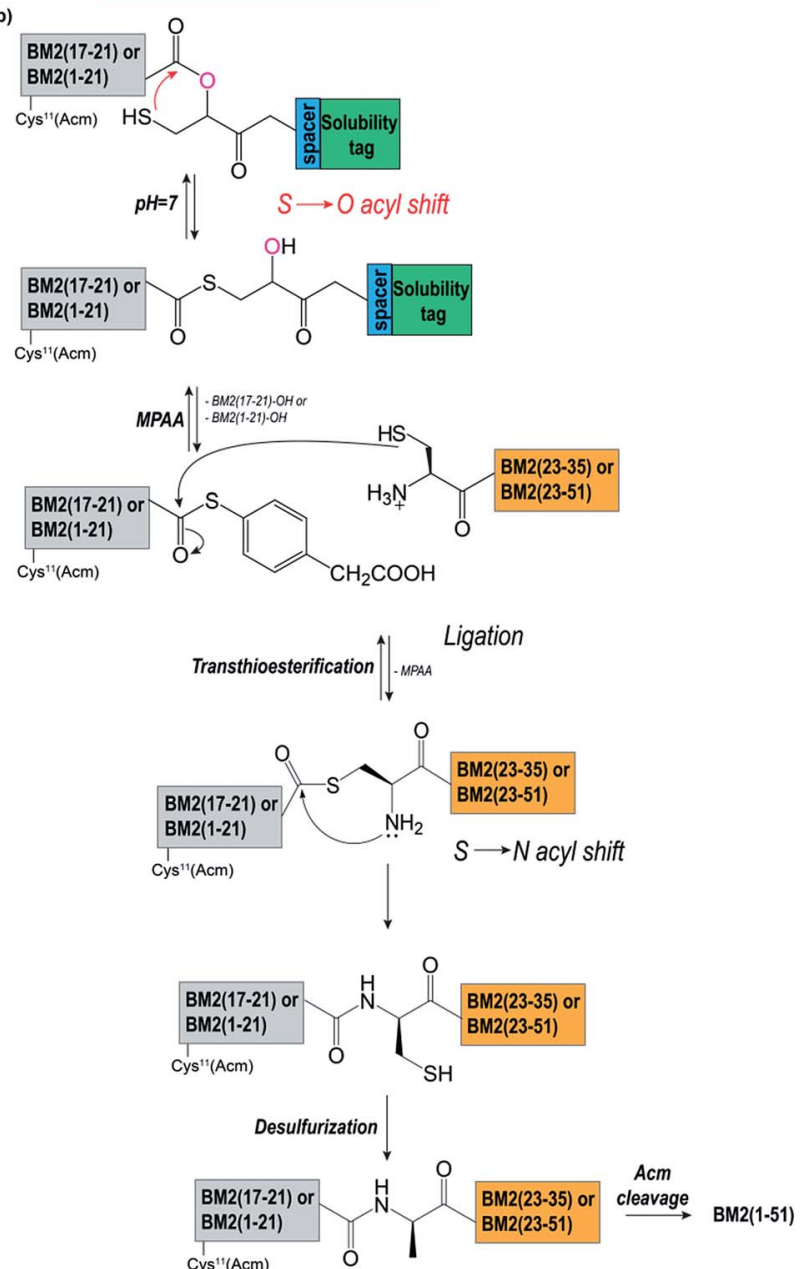

Fig. 1 (a) The amino acid sequence of BM2(1-51). The membrane spanning helical region is highlighted in yellow. Residues lle21 and Ala22 were mutated to Leu and Cys respectively. The Hmp-fragments $\left[\mathrm{Cys}^{11}(\mathrm{Acm})\right] \mathrm{BM} 2(1-21) / \mathrm{BM} 2(17-21)$ are coloured in grey. The Cysfragments $\left[\mathrm{Cys}^{22}\right] \mathrm{BM} 2(22-51) /\left[\mathrm{Cys}^{22}\right] \mathrm{BM} 2(22-35)$ are coloured in orange. (b) The NCL protocol as applied for the synthesis of BM2(1-51). The Hmp-fragment BM2(17-21) or [Cys $\left.{ }^{11}(\mathrm{Acm})\right] \mathrm{BM} 2(1-21)$ formed the thioester at $\mathrm{pH} 7$ via an $\mathrm{S}$ to $\mathrm{O}$-acyl shift followed by attachment of the Cys-fragment $\left[\mathrm{Cys}^{22}\right] \mathrm{BM} 2(22-35)$ or $\left[\mathrm{Cys}^{22}\right] \mathrm{BM} 2(22-51)$. Simultaneously, the cleavage of the solubilizing tag occurred. Then, the MPAA-catalysed transesterification was followed by an irreversible $S$ to $\mathrm{N}$-acyl shift. Finally, Cys22 was converted to Ala22 through desulfurization, and the Acm protecting group was cleaved from Cys11.

The thioester-forming peptides ALHFL-Hmp (1), ALHFLHmp-ADO (2), ALHFL-Hmp-ADO 2 (3), and ALHFL-Hmp-ADOLys $_{5}$ (4) were obtained as Hmp-diastereomers in yields between 20-60\% (Table S2, Fig. S4, S5 $\dagger$ ). The crude peptides 1-3 were directly subjected to the ligation experiments (Fig. S4a-c $\dagger$ ), whereas peptides 4-5 were first purified by RP-HPLC (Fig. S4d, $\mathrm{S} 5 \dagger$ ). Two dipeptides were synthesized in order to analyse whether the first amino acid (L-Leu), which is coupled to Hmp via the Mitsunobu reaction, ${ }^{60}$ is prone to racemization: ${ }^{\mathrm{L}-\mathrm{Ph}} \mathrm{C}-\mathrm{L}-$ Leu-Hmp and L-Phe-D-Leu-Hmp. HPLC analysis revealed different retention times for both dipeptides upon coelution, indicating that $\mathrm{L}$-Leu does not racemize upon coupling to the racemic Hmp (Fig. S4e, $\mathrm{f}_{\dagger}^{\dagger}$ ). The desired peptides were stored at $-20{ }^{\circ} \mathrm{C}$, and neither degradation nor hydrolysis was observed. This is a significant advantage of our HMP-thioester strategy in comparison to methods where thioester-peptides, which are unstable at higher $\mathrm{pH}$, are synthesized in a multistep reaction (i.e. on 4-sulfamylbutyryl resin).$^{61}$

The model peptides 1-4 were ligated to the Cys-fragment $\mathrm{BM} 2(22-35)$ (5) at a molar ratio of $1: 2$ in ligation buffer A, and were very soluble under these conditions (Table S6†). We noticed already at this step that peptide 4 , possessing the Lys solubilizing tag attached to the Hmp unit, is the least hydrophobic, eluting at $\sim 22 \%$ of eluent B (acetonitrile containing $0.1 \%$ TFA). This is in comparison to peptides $1-3$, which all elute at $\sim 32 \%$ of eluent $\mathrm{B}$, and possess $\mathrm{ADO}, \mathrm{ADO}_{2}$ or no solubilizing tag (Fig. 2a-d). Consequently, $\mathrm{ADO}$ and $\mathrm{ADO}_{2}$ did not influence the solubility of the respective model peptide in comparison to the reference peptide 1 .

The ligations for the model peptides 1-4 were completed within 2 hours (Fig. 2), and no further changes were observed at longer reaction times ( $>2 \mathrm{~h})$, according to the RP-HPLC analysis. For peptide 1, the BM2(17-21)-MPAA thioester, which is generated through the in situ rearrangement of Hmp and reaction with MPAA, was already present directly after starting the ligation. However, for peptides 2-4 the maximum amount of the thioester was formed at $30 \mathrm{~min}$ (Fig. 2b). The newly formed thioester-intermediate was subsequently converted into the MPAA-thioester, which was then ligated through transthioesterification with the C-terminal Cys of the BM2(22-35) (5) fragment. After the $S$ to $N$-acyl shift, the final peptide ALHFLCWTIGHLNQIKRGI (BM2(17-35) (6)) (Fig. 1b and 2d) was obtained in $80-90 \%$ yield, according to the HPLC data (Table S3†).

As already mentioned above and in accordance with the literature, the only byproduct formed during the ligation process was from hydrolysis of the carboxyester. ${ }^{49,51}$ According to the RP-HPLC analysis, 13-16\% of the side product ALHFL$\mathrm{C} \alpha \mathrm{OOH}$ was formed during the ligation reactions of 1-4 with 5 (Table S3,† Fig. 2), which is comparable to the literature data. ${ }^{49,51}$

However, the final yields of the product 6 during the ligation reaction of the peptides 1-4 with $\mathbf{5}$ were similar, ranging from $80-90 \%$. Hence, the introduction of a solubilizing tag into the model peptide 1 , resulting in the peptides 2 (ADO), $3\left(\mathrm{ADO}_{2}\right)$ and $4\left(\mathrm{ADO}^{-\mathrm{Lys}_{5}}\right)$, did not impair the efficiency of the ligation reaction. Furthermore, our results indicate reaction times of less than $2 \mathrm{~h}$ for the NCL of 1-4 with 5.

\section{Application of the NCL strategy for the synthesis of BM2(1-51)}

Encouraged by the results for the NCL of the model peptides 1-4 with $\mathbf{5}$, we decided to apply this strategy to longer and more hydrophobic peptides. Hence, we intended to synthesize a BM2 fragment which comprises residues $1-51$, and now includes the full transmembrane domain and parts of the cytosolic part of the M2 protein. As for the model peptides 1-4, Ala22 was chosen as the respective ligation point, and thus mutated to Cys22 
a)
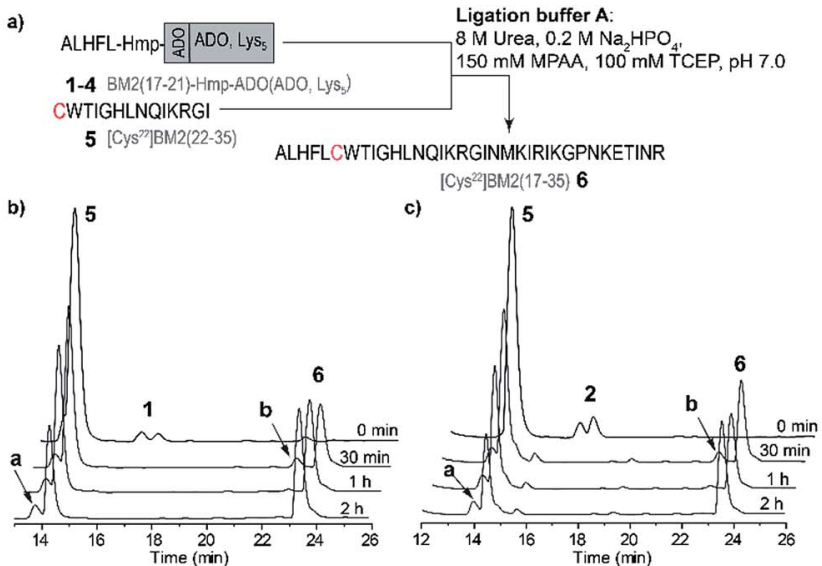

d)

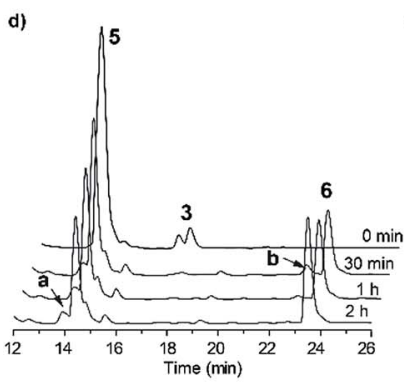

e)

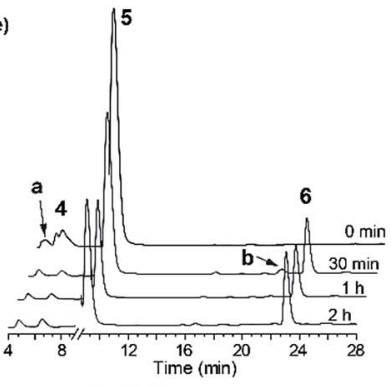

f)

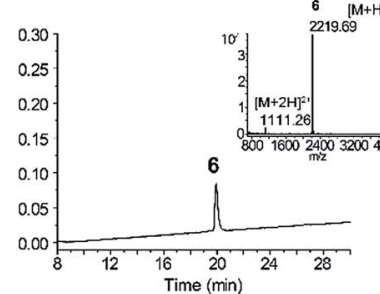

Fig. 2 (a) A schematic representation of the NCL strategy in ligation buffer A for the model peptides. (b-e) RP-HPLC elution profiles of the model peptide ligations: (b) ALHFL-Hmp (1), (c) ALHFL-Hmp-ADO (2), (d) ALHFL-Hmp-ADO 2 (3) and (e) ALHFL-Hmp-ADO-Lys 5 (4) with the Cys-fragment BM2(22-35) (5). The MPAA peak was removed from the chromatogram for better visibility. (f) RP-HPLC of the purified ligation product BM2(17-35) (6) and ESI-MS spectrum (inset). HPLC conditions: (b-d) $15-45 \%$ eluent B over 30 min, (e) $20-40 \%$ eluent B over $30 \mathrm{~min}$ and (f) $15-45 \%$ eluent $B$ over $30 \mathrm{~min}$. The hydrolyzed ester $\mathrm{BM} 2(17-21)-\mathrm{C} \alpha \mathrm{OOH}$ is indicated by $\mathrm{a}$ in the elution profiles, and BM2(17-21)-MPAA thioester is indicated by $b$.

(Fig. 1). Moreover, the thiol of Cys11 was protected with Acm in order to prevent a possible cyclization reaction (viz. reaction of the thiol group with the thioester) during the NCL. In analogy to the NCL strategy for the model peptides, $\mathrm{ADO}_{2}$ and $\mathrm{Lys}_{5}$ solubilizing tags were employed in combination with the Hmp unit (9-10, Table S2, Fig. S6 $\dagger$ ) for the thioester-forming peptide $\left[\mathrm{Cys}^{11}(\mathrm{Acm})\right] \mathrm{BM} 2(1-21)$. Additionally, we synthesized BM2(121) (7) and $\left[\mathrm{Cys}^{11}(\mathrm{Acm})\right] \mathrm{BM} 2(1-21)-\mathrm{Hmp}(8)$ as references.

Peptides 7-11 were synthesized as described earlier for the model peptides. For peptides 8-10, 2-methylpiperidine (2-MP) was used for Fmoc-deprotection to avoid premature peptide cleavage from the resin. ${ }^{51}$

In the following sections, the NCL of the peptides 8-10 with the peptide fragment $\mathbf{1 1}$ was performed in three different ligation buffers, namely phosphate buffer (named buffer from hereon), buffer/trifluoroethanol (2:1, v/v) and buffer/ hexafluoro-2-propanol $(2: 1, \mathrm{v} / \mathrm{v})$.

\section{Ligation reaction in phosphate buffer (buffer A)}

Due to the high hydrophobicity of the thioester forming $\left[\mathrm{Cys}^{11}(\mathrm{Acm})\right] \mathrm{BM} 2(1-21)$ peptide fragment, peptides 8 and $\mathbf{9}$ were not soluble in the standard ligation buffer, disallowing the NCL of these peptides. In contrast, a significant improvement of the solubility was achieved for the peptide $\left[\mathrm{Cys}^{11}(\mathrm{Acm})\right] \mathrm{BM} 2(1-21)-$ Hmp-ADO-Lys $_{5}$ (10), allowing for an efficient ligation with the Cys-fragment $\left[\mathrm{Cys}^{22}\right] \mathrm{BM} 2(22-51)$ (11) (Fig. 3) under standard ligation conditions in phosphate buffer (ligation buffer A).

In analogy to the model peptides, the $\left[\mathrm{Cys}^{11}(\mathrm{Acm})\right] \mathrm{BM} 2(1-$ 21)-MPAA thioester was formed directly after the reaction was started (Fig. 3), indicating that the MPAA-thioester formation does not depend on the peptide length. Interestingly, the ligation reaction took much longer to complete compared to the model peptides, almost fully converting the $\left[\mathrm{Cys}^{11}(\mathrm{Acm})\right]$ BM2(1-21)-MPAA thioester into the ligation product [Cys $\left.{ }^{11}(\mathrm{Acm}), \mathrm{Cys}^{22}\right] \mathrm{BM} 2(1-51)$ (12a) after $24 \mathrm{~h}$ (Fig. 3). In comparison to the ligation of the model peptide ALHFL-Hmp$\mathrm{ADO}^{-\mathrm{Lys}_{5}} 4$, the amount of hydrolyzed carboxyester [Cys $\left.{ }^{11}(\mathrm{Acm})\right]$ $\mathrm{BM} 2(1-21)-\mathrm{C}^{\alpha} \mathrm{OOH}$ was nearly the same $(20 \%)$, resulting in an overall $80 \%$ yield of the desired product [Cys ${ }^{11}(\mathrm{Acm}), \mathrm{Cys}^{22}$ ] BM2(1-51) (12a) (Table S3 and S4 $\dagger$ ). In summary, our ligation conditions and the proposed synthesis of the thioester-forming fragment, possessing a combination of solubilizing tags $\left(\mathrm{Lys}_{5}\right)$
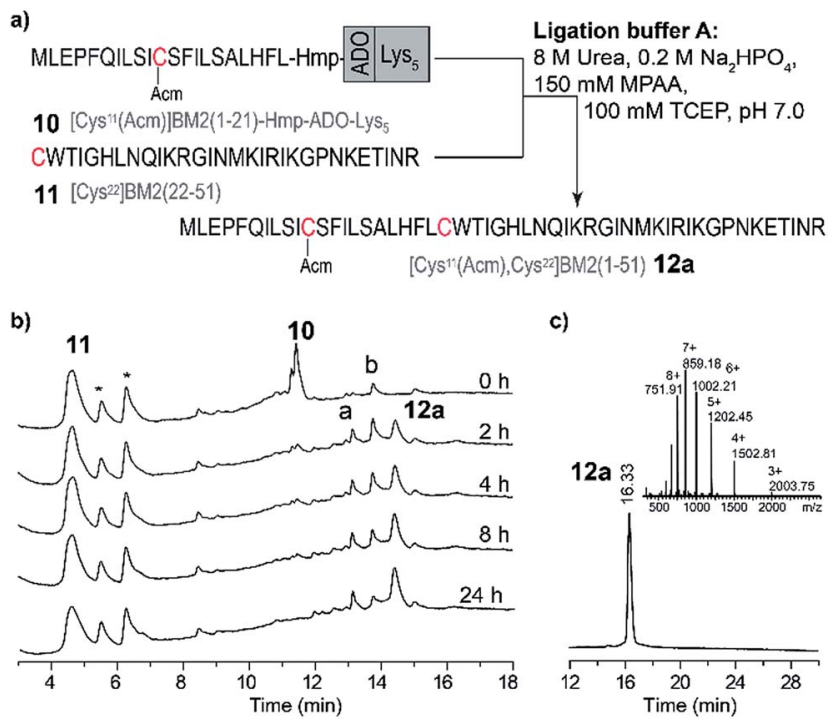

Fig. 3 Ligation of $\left[\mathrm{Cys}^{11}(\mathrm{Acm})\right] \mathrm{BM} 2(1-21)-\mathrm{Hmp}-\mathrm{ADO}-\mathrm{Lys}_{5}$ with [Cys ${ }^{22}$ ]BM2(22-51) in the ligation buffer A. (a) Schematic representation of the NCL strategy in the ligation buffer A. (b) RP-HPLC chromatograms of the reaction mixture at different times. RP-HPLC conditions: $10-20 \%$ eluent B over 5 min followed by $20-70 \%$ eluent B over $20 \mathrm{~min}$. (c) RP-HPLC of the purified ligation product $\left[\mathrm{Cys}{ }^{11}(\mathrm{Acm})\right.$, ${ }^{22}$ Cys]BM2(1-51) (12a) and the ESI-MS spectrum (inset). The hydrolyzed ester $\left[\mathrm{Cys}^{11}(\mathrm{Acm})\right] \mathrm{BM} 2(1-21)-\mathrm{C}^{\alpha} \mathrm{OOH}$ is labelled with a. [Cys $\left.{ }^{11}(\mathrm{Acm})\right]-B M 2(1-21)-M P A A$ thioester is labelled with $b .{ }^{*}$ - peaks from the ligation solution. 
and the thioester-forming Hmp unit, result in high yields (80\%) of the desired product, and can be used generally for the NCL of highly hydrophobic peptide thioester-fragments. Even though our data already indicated a significant improvement for the NCL of hydrophobic peptides, we sought to further improve the anticipated strategy by suppressing the carboxyester formation. Therefore, we used 2,2,2-trifluoroethanol (TFE) or hexafluoro-2propanol (HFIP), which were added to the ligation buffer A in a $1: 2(\mathrm{v} / \mathrm{v})$ ratio, resulting in the ligation buffer B or C (Table $\mathrm{S} 6 \dagger)$, respectively. TFE was previously described as an efficient additive of the ligation reaction for the synthesis of the M2 protein from influenza A virus. ${ }^{12,62}$

\section{Ligation reaction in trifluoroethanol/phosphate buffer (buffer B)}

In contrast to the NCL under standard conditions using the phosphate buffer (buffer A), the thioester-forming fragments 8$\mathbf{1 0}$ and Cys-fragment $\mathbf{1 1}$ were highly soluble in the TFEcontaining ligation buffer B. However, during the NCL of 9 and 11 (Fig. 4a), the product formation of $\left[\mathrm{Cys}^{11}(\mathrm{Acm}), \mathrm{Cys}^{22}\right]$ BM2(1-51) (12) seemed to be completed after $2 \mathrm{~h}$, while the amount of the hydrolyzed carboxyester $\left(\left[\mathrm{Cys}^{11}(\mathrm{Acm})\right] \mathrm{BM} 2(1-21)-\right.$ $\left.\mathrm{C}^{\alpha} \mathrm{OOH}\right)$ continuously increased throughout the entire reaction process. Interestingly, the amount of the Cys-fragment $\left[\mathrm{Cys}^{22}\right]$ BM2(22-51) (11, $\left.t_{\mathrm{R}} 5.71 \mathrm{~min}\right)$ continuously decreased, with the continuous formation of an unknown side product $\left(\mathbf{1 1}^{\prime}\right)$ observed at $t_{\mathrm{R}} 5.78 \mathrm{~min}$ (Fig. 4a). As concluded from the HPLC chromatograms, this side product appears to be unreactive towards the formation of the ligation product 12. A detailed analysis of this newly formed side product, using HPLC, ESI-MS and CD spectroscopy, revealed that $\mathbf{1 1}^{\prime}$ directly resulted from $\mathbf{1 1}$, presumably induced by TFE (Fig. 4).

This interpretation is further supported by the fact that $\mathbf{1 1}^{\prime}$ was directly formed in an aqueous TFE solution. In contrast, peptide $\mathbf{1 1}$ was totally stable in an aqueous HFIP solution, concluding that the strong helix-inducing effect of TFE and HFIP is not responsible for the formation of $\mathbf{1 1}^{\prime}$, as further indicated by the $\mathrm{CD}$ spectra shown in Fig. 4d. Finally, MS spectrometry uncovered a difference of $\mathrm{m} / \mathrm{z}=26$ when comparing $\mathbf{1 1}^{\prime}$ to $\mathbf{1 1}$, indicating a TFE-induced chemical modification (Fig. 4e and f), presumably with formation of a 2oxo-4-thiazolidine with the N-terminal Cys. ${ }^{63,64}$ In 1987, D'Ischia et al. described the reaction of aminothiols with $1,1^{\prime}$-carbonyldiimidazole, resulting in the formation of 2-oxo-4thiazolidines. ${ }^{63}$ The TFE-induced formation of a 2-oxo-4thiazolidine nicely explains the inactivation of $\mathbf{1 1}$ under the NCL conditions and the difference in $M_{\mathrm{w}}$ of $m / z=26$. We suggest that urea would act in the same way as $1,1^{\prime}$-carbonyldiimidazole in this reaction, providing the carbonyl group at the 2 position of the thiazolidine ring. The calculated isotopic pattern for this suggested 2-oxo-4-thiazolidine modified [ $\left.\mathrm{Cys}^{22}\right]$ BM2(22-51) is in good agreement with the experimental isotopic pattern (Fig. 4f). Moreover, the formation of such a non-reactive side product nicely explained the rather high amount of the hydrolyzed carboxyester $(\sim 45 \%)$ under these conditions, since the Cys-fragment is not available for the

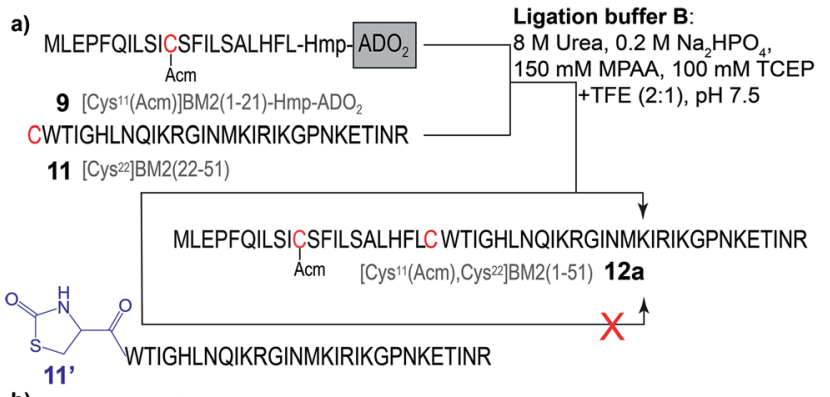

b)
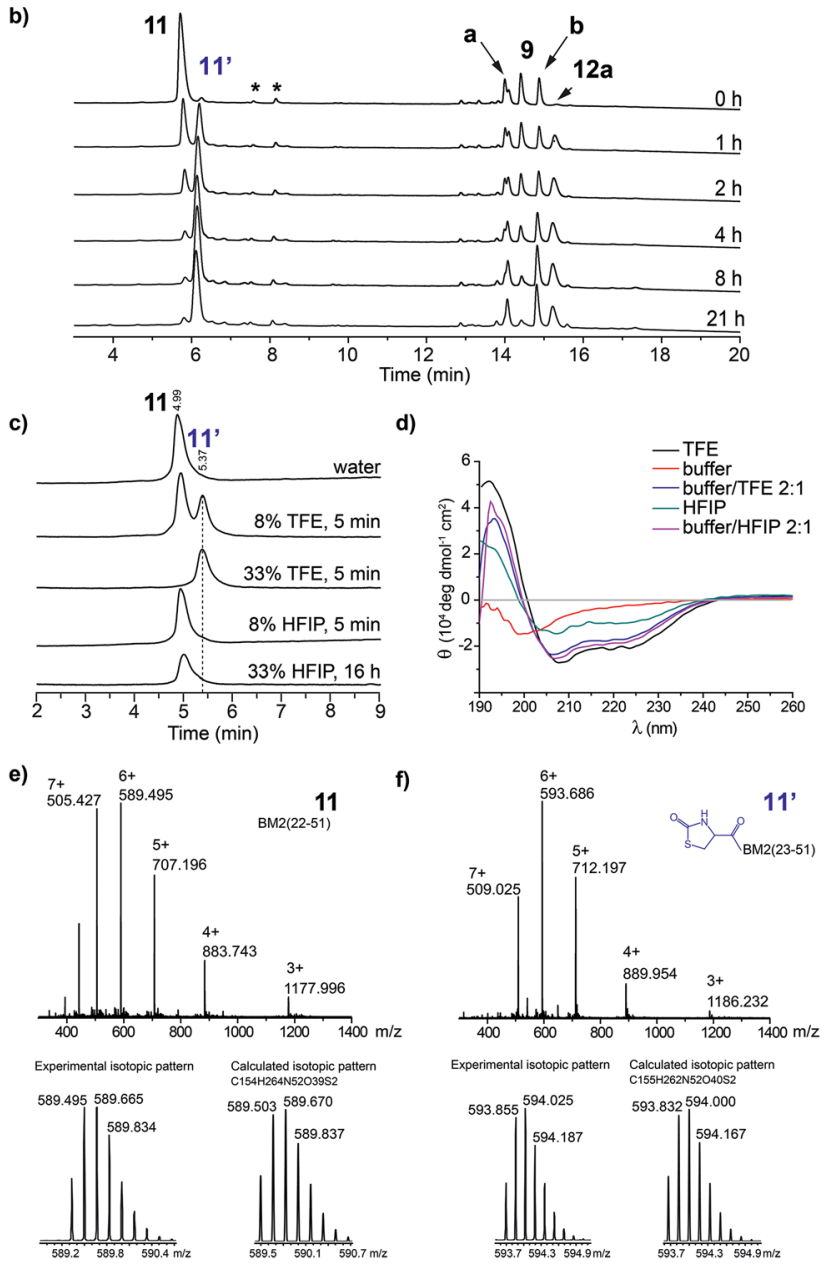

Fig. 4 (a) Schematic representation of the NCL in the ligation buffer B. (b) RP-HPLC chromatograms of the ligation reaction mixture of [Cys ${ }^{22}$ ] $\mathrm{BM} 2(22-51)$ with $\left[\mathrm{Cys}^{11}(\mathrm{Acm})\right] \mathrm{BM} 2(1-21)-\mathrm{Hmp}-\mathrm{ADO}_{2}$ (10). The hydrolyzed ester $\left[\mathrm{Cys}^{11}(\mathrm{Acm})\right] \mathrm{BM} 2(1-21)-\mathrm{C}^{\alpha} \mathrm{OOH}$ is indicated as a. The $\left[C^{11}(\mathrm{Acm})\right] B M 2(1-21)-M P A A$ thioester is indicated as b. Peaks which result from the ligation buffer are indicated with *. HPLC conditions: $10-20 \%$ eluent B over 5 min followed by $20-70 \%$ eluent B over $15 \mathrm{~min}$ at a flow rate of $2 \mathrm{~mL} \mathrm{~min}^{-1}$. (c) HPLC analysis of [Cys ${ }^{22}$ BMM2(22-51), which was incubated in different solutions. HPLC conditions: $10-40 \%$ eluent $B$ over $15 \mathrm{~min}$ at a flow of $2 \mathrm{~mL} \mathrm{~min}^{-1}$. (d) CD spectra of [Cys ${ }^{22}$ ] $\mathrm{BM} 2(22-51)$ recorded in different solutions. (e) MS spectrum of [Cys ${ }^{22}$ ] BM2(22-51) 11 ( $\left.t_{R} 5.71 \mathrm{~min}\right)$, and experimental vs. calculated isotopic pattern. (f) MS spectrum of [Cys ${ }^{22}$ ]BM2(22-51) $11^{\prime}$ ( $\left.t_{R} 5.78 \mathrm{~min}\right)$, and experimental $v s$. calculated isotopic pattern.

ligation reaction, and the thioester fragment hydrolyses to a great extent. In particular, the reaction mechanism was not analyzed further, since we found that HFIP is a good alternative 
to TFE during the NCL, without forming any unreactive product with the peptide.

\section{Ligation reaction in hexafluoro-2-propanol/phosphate buffer (buffer C)}

Because of the stability of $\mathbf{1 1}$ in HFIP (Fig. 4c), a third ligation buffer system (Table S6†) was tested. Due to the reduced solubility in HFIP of the ligation additives TCEP, MPAA and urea, they were used in slightly lower concentrations (Fig. 4 and 5). As outlined in Fig. 5, the NCL of the peptide fragments 8-10 with 11 was completed within $24 \mathrm{~h}$, almost quantitatively forming the product 12a. For $\left[\mathrm{Cys}^{11}(\mathrm{Acm})\right] \mathrm{BM} 2(1-21)-\mathrm{Hmp}(8)$ and $\left[\mathrm{Cys}^{11}(\mathrm{Acm})\right] \mathrm{BM} 2(1-21)-\mathrm{Hmp}-\mathrm{ADO}_{2}(\mathbf{9})$, we were able to separate the two diastereomers which resulted from the racemic HMP building block used for the synthesis of 8-10, allowing us to conclude that they are equally reactive. They also form similar and low amounts $(\sim 4-12 \%$, Table $\mathrm{S} 4 \dagger)$ of hydrolyzed carboxyester. The reason for the lower hydrolysis rate observed in the ligation buffer $\mathrm{C}$ might be due to a lower water content in the
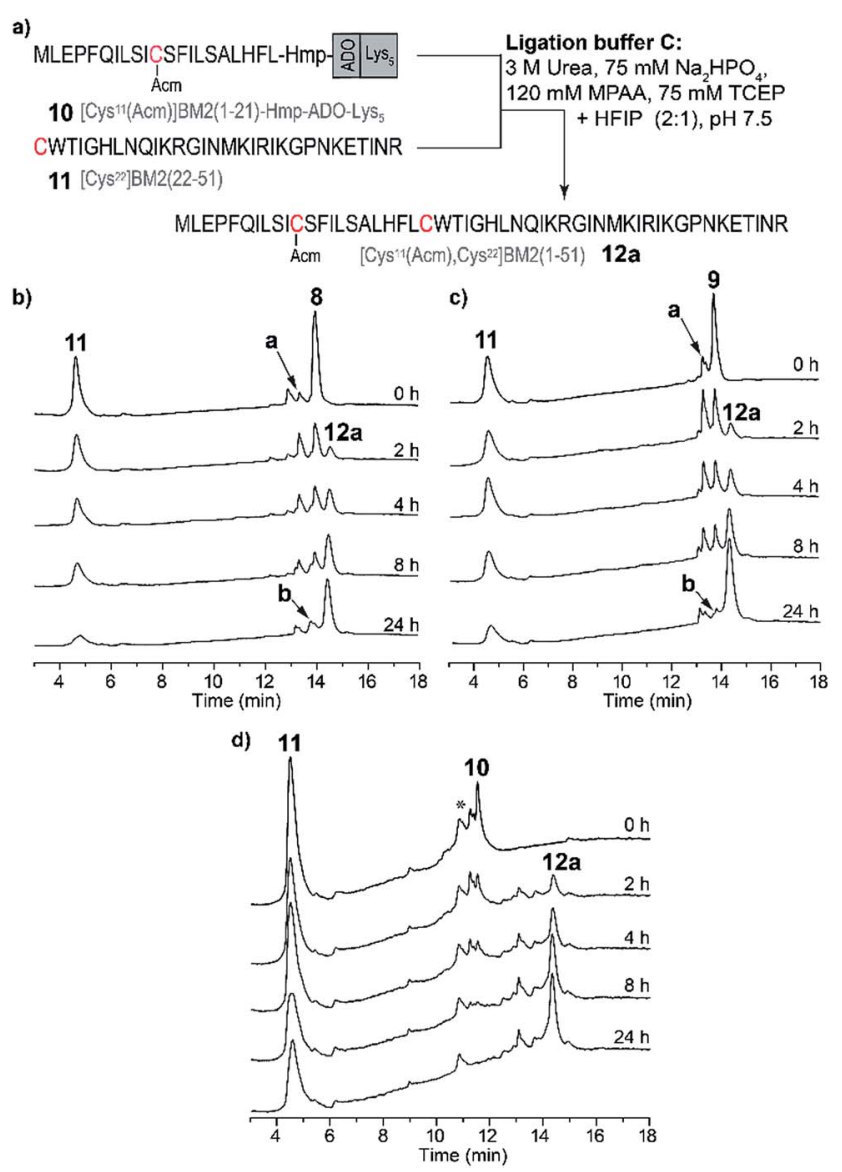

Fig. 5 (a) Schematic representation of the NCL in the ligation buffer $C$. RP-HPLC chromatograms of the ligation reaction mixtures of the Cysfragment [Cys $\left.{ }^{22}\right] \mathrm{BM} 2(22-51)$ (11) with (b) $\left[\mathrm{Cys}^{11}(\mathrm{Acm})\right] \mathrm{BM} 2(1-21)-\mathrm{Hmp}$ (8), (c) $\left[\mathrm{Cys}^{11}(\mathrm{Acm})\right] \mathrm{BM} 2(1-21)-\mathrm{Hmp}-\mathrm{ADO}_{2}$ (9) and (d) $\left[\mathrm{Cys}^{11}(\mathrm{Acm})\right]$ BM2(1-21)-Hmp-ADO-Lys 5 (10). Hydrolyzed carboxyester $\left[\mathrm{Cys}^{11}(\mathrm{Acm})\right] \mathrm{BM} 2(1-21)-\mathrm{C}^{\alpha} \mathrm{OOH}$ is highlighted as a. $\left[\mathrm{Cys}^{11}(\mathrm{Acm})\right]$ BM2(1-21)-MPAA thioester is highlighted as $b$. Some impurities on the HPLC chromatogram (d) are highlighted with *. buffer $\mathrm{C}$ in comparison to the buffer A, thus resulting in a faster reaction with the Cys-peptide.

\section{Desulfurization and Acm-group deprotection of BM2(1-51) (12a)}

After the successful ligation of the BM2(1-51) proton channel through our HMP-strategy we focused on the backtransformation of the modifications, which we introduced with respect to our ligation strategy, namely cysteine at position 21 and an Acm protecting group at position 11. Hence, Cys21 was transformed into Ala through a desulfurization step, followed by cleavage of the Acm protecting group from Cys11.

Desulfurization of the Cys residues expands the number of possible ligation sites. ${ }^{65}$ This is especially of importance for peptides which have no naturally occurring or suitable Cys residues for the anticipated ligation strategy.

The desulfurization of Cys21 was achieved using the method introduced by Danishefsky et al. ${ }^{66}$ which was optimized due to the insolubility of peptide 12a in the desulfurization buffer.

Lastly, desulfurization was accomplished by the addition of the radical initiator VA-044 (2,2-azobis[2-(2-imidazolin-2-yl) propane]dihydrochloride) in the presence of reduced glutathione and an excess of tris(2-carboxyethyl)phosphine in a buffer/HFIP emulsion.

A nearly quantitative conversion of Cys to Ala was achieved for the peptide 12a (within $6 \mathrm{~h}$, Fig. 6b, Table S $5 \dagger$ ), yielding peptide 12b. Interestingly, we found that by using this method, almost quantitative desulfurization can be accomplished for the soluble peptide 5 within $4 \mathrm{~h}$ (Fig. S7†). This result is similar to that described for small hydrophilic peptides in the literature, however the yield was reported to vary (80-99\%) depending on the peptide sequence. ${ }^{65,66}$

Finally, for the cleavage of the Acm protection group from Cys11 to obtain 12c, three different methods were tested using iodine oxidation, ${ }^{67,68}$ a silver salt, ${ }^{69-74}$ and DTNP. ${ }^{75-78}$ The DTNP approach, however, failed in our hands, probably because of the presence of Met and Trp in the primary structure of our peptide 12. ${ }^{79}$ Using iodine oxidation we achieved only very poor yields ( $\sim 16 \%$ ) of the final product 12c (Fig. S8 $\dagger$ ). The Acm deprotection employing silver trifluoromethanesulfonate (AgOTf) resulted in a final yield of $\sim 60 \%$ of 12c (Fig. 6c) after HPLC purification, which is comparable to the literature results for the hydrophilic peptide oxytocin. ${ }^{70}$ The peptide $12 \mathrm{c}$ was finally purified (Fig. 6d and e, Table S5 $\dagger$ ) and subjected to CD analysis.

\section{Structural indications of the synthetic BM2(1-51)}

In order to analyze whether the $\mathrm{BM} 2(1-51)$ protein fragment (12c) would correctly fold, the final product 12c was subjected to CD analysis. Additionally, the far UV CD spectra of BM2(1-21) (7) and $\mathrm{BM} 2(1-51)(\mathbf{1 2 a})$ at $20{ }^{\circ} \mathrm{C}$ were first measured in TFE (Fig. 7). All spectra showed the characteristic double minima at $209 \mathrm{~nm}$ and $223 \mathrm{~nm}$, which are typical for an $\alpha$-helical fold (Fig. 7). After deconvolution of the CD spectra, it was found that the peptides 12a and 12c and fragment 7 largely exist in an $\alpha$ helical form (Table $S 7 \dagger$ ), containing around $70 \% \alpha$-helix. As a reference, the BM2(1-33) fragment revealed around $60 \% \alpha$ - 

MLEPFQILSICSFILSALHFLCWTIGHLNQIKRGINMKIRIKGPNKETINR Acm [Cys'1(Acm),Cys $\left.{ }^{2}\right] \mathrm{BM} 2(1-51)$ 12a Desulfurization TCEP/VA044/GSH/HFIP $\mathrm{GdnHCl} / \mathrm{Na}_{2} \mathrm{HPO}_{4}$ buffer

MLEPFQILSICSFILSALHFLAWTIGHLNQIKRGINMKIRIKGPNKETINR Acm [Cys $\left.{ }^{11}(A c m)\right] B M 2(1-51)$ 12b Acm-group cleavage
AgOTf/anisole/TFA
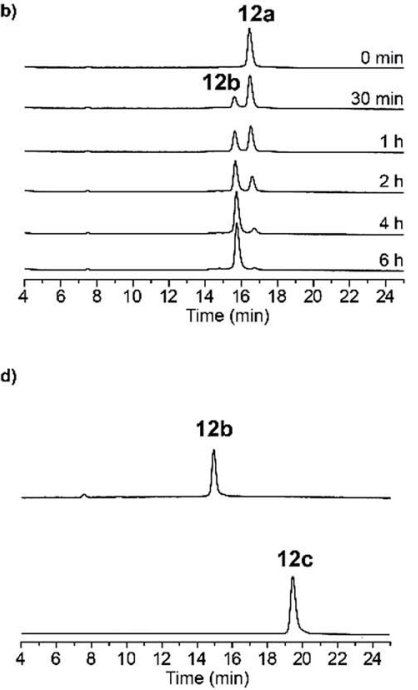

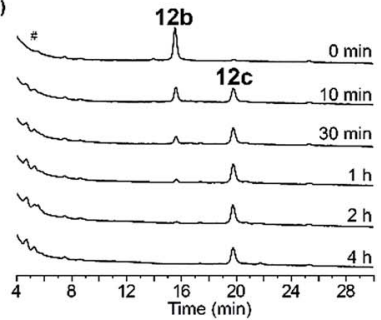

e)

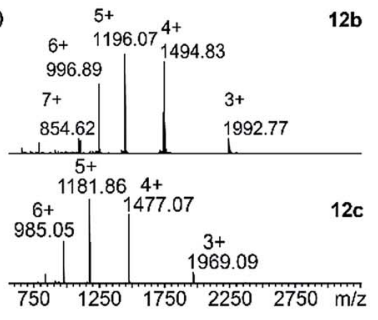

Fig. 6 (a) Schematic representation of the post-NCL desulfurization (product $12 \mathrm{~b}$ ) and cleavage of the Acm-group reactions leading to the final product BM2(1-51) (12c). Reaction conditions are highlighted for each step. (b) RP-HPLC elution profiles of the reaction mixture during desulfurization at different time points (directly after the reaction start (0 min)-6 h). (c) RP-HPLC elution profiles of the reaction mixture during cleavage of the Acm-group at different time points (directly after the reaction start (0 $\mathrm{min})-4 \mathrm{~h})$. \# - injection peak. (d) RP-HPLC elution profiles of the purified products $\left[\left(\mathrm{Cys}^{11}(\mathrm{Acm})\right] \mathrm{BM} 2(1-51)\right)(12 \mathrm{~b}$, upper trace) and the final product BM2(1-51) (12c, bottom trace). (e) ESI-MS spectra of $\left[\left(\mathrm{Cys}^{11}(\mathrm{Acm})\right] \mathrm{BM} 2(1-51)\right)(12 \mathrm{~b}$ upper spectrum) and BM2(1-51) (12c, bottom spectrum).

helical content under these conditions. Moreover, deconvolution of the CD spectra of the BM2 fragments 7 and 12c and BM2(1-33) in POPC (1-palmitoyl-2-oleoylphosphatidylcholine)
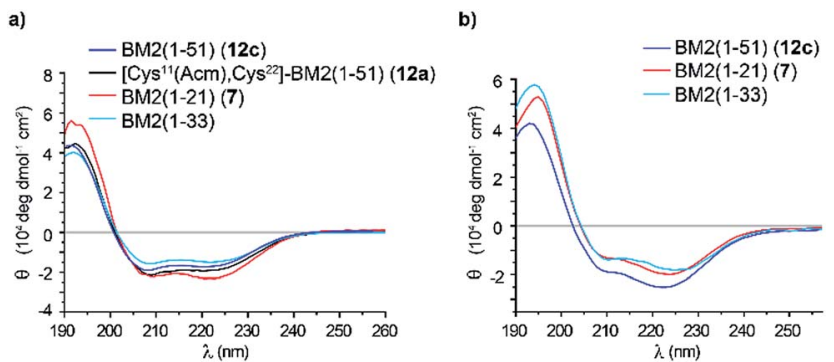

Fig. 7 Structural indications for BM2(1-51) (12c). (a) The overlay of the CD spectra: BM2(1-51) (12c, blue), BM2(1-51) (12a, black), BM1(1-21) (7, red) and $B M 2(1-33)$ (cyan) in TFE. (b) CD spectra of BM2(1-51) (12c, blue), BM1(1-21) (7, red) and BM2(1-33) (cyan) in POPC lipid membrane. revealed a similar $\alpha$-helical content of approx. $60 \%$ for all three BM2 fragments.

These findings are also in line with the recent structural data from a solid-state NMR study of BM2(1-33), which indicated an almost fully $\alpha$-helical structure. ${ }^{54}$ Consequently, BM2(1-51) (12c) appears to be structurally very similar compared to its shorter counterpart BM2(1-33), and this might indicate some ordered helical structure for the region between residues 34 and 44, which was predicted to be structurally disordered from a solution NMR study of the full length BM2. ${ }^{54}$

\section{Conclusion}

In conclusion, the use of a removable solubilizing tag combined with an oxo-ester functional unit is an effective method for the synthesis and purification of highly hydrophobic peptide fragments. The oxo-ester peptide can be effectively used for the native chemical ligation with cysteine-containing peptide fragments, as demonstrated by the synthesis of the influenza virus B proton channel fragments BM2(17-35) and BM2(1-51). Moreover, our strategy allows the incorporation of various solubilizing tags into an oxo-peptide sequence, which was shown by the example of $\mathrm{ADO}, \mathrm{ADO}_{2}$ or $\mathrm{ADO}-\mathrm{Lys}_{5}$ tags. For the native chemical ligation, the Ala22 residue was replaced with Cys22, and Cys11 was protected with an Acm-group. Both modifications were fully reversible through desulfurization (99\% yield) and Acm-group cleavage (60\% yield) after the careful optimization of existing literature protocols for our hydrophobic peptides. Finally, circular dichroism analysis of the BM2 fragments, BM2(1-21) and BM2(1-51), in TFE and reconstituted in POPC revealed that the synthetic peptide exists mainly as an $\alpha$ helical structure, similar to the recently characterized BM2(1$33)$, indicating that the structurally disordered region between residues $34-44$ most likely possesses an $\alpha$-helix structure.

The current study will provide an important alternative method to prepare highly hydrophobic peptides and proteins, allowing their synthesis in a multi-milligram scale, i.e. for future structural and binding studies.

\section{Experimental section}

\section{Synthesis of 3-chloro-2-hydroxypropanoic acid}

A $3 \mathrm{M}$ solution of 3-chloro-1,2-propanediol ( $0.09 \mathrm{~mol})$ in $30 \mathrm{~mL}$ nitric acid (conc.) was slowly heated to $80{ }^{\circ} \mathrm{C}$ until a vigorous reaction started. The temperature was kept at $80{ }^{\circ} \mathrm{C}$ for $20 \mathrm{~min}$ and then warmed-up to $100{ }^{\circ} \mathrm{C}$ for $30 \mathrm{~min}$. Subsequently, the reaction solution was cooled to room temperature and neutralized with sodium bicarbonate. The product was extracted with diethyl ether, and the organic layer was dried over anhydrous sodium sulfate before the solvent was removed under reduced pressure. The residual solvent was evaporated to leave a viscous liquid. The product was precipitated in cold chloroform and filtered to obtain $7.4 \mathrm{~g}$ of 3-chloro-2hydroxypropanoic acid (yield: 66\%). NMR (DMSO-d $\mathrm{d}_{6}$ ): $\delta 3.77$ $\left(2 \mathrm{H}, \mathrm{CH}^{\beta}\right), 4.30\left(1 \mathrm{H}, \mathrm{CH}^{\alpha}\right)$ (Fig. S1†). 


\section{Synthesis of 2-hydroxy-3-(triphenylmethyl)thio-propanoic acid (Hmp(Trt)-OH)}

A $1 \mathrm{M}$ solution of 3-chloro-2-hydroxypropanoic acid $(0.047 \mathrm{~mol})$ in dry 1,2 -dimethoxyethane was cooled to $0{ }^{\circ} \mathrm{C}$, and sodium hydride $(60 \% \mathrm{~m} / \mathrm{m}$ dispersion in mineral oil, $0.047 \mathrm{~mol})$ was added slowly. A solution of triphenylmethanethiol $(0.05 \mathrm{~mol})$ and sodium hydride ( $60 \%$ dispersion in mineral oil, $0.047 \mathrm{~mol}$ ) in dry 1,2-dimethoxyethane was added dropwise, and the resulting reaction mixture was stirred for $4 \mathrm{~h}$. Afterwards, the solvent was removed under reduced pressure yielding a yellow, solid residue, which was dissolved in a diethyl ether/water mixture $(1: 1)$. The aqueous phase was separated, washed with diethyl ether and acidified with $1 \mathrm{M}$ hydrochloric acid. The product was extracted with ethyl acetate. Finally, the organic layer was dried over anhydrous sodium sulfate and the solvent was removed under reduced pressure until a highly viscous liquid was left. The liquid was solidified overnight in the refrigerator and the rest of the solvent was removed under reduced pressure until a slightly yellow powder was obtained. Yield: $11.08 \mathrm{~g}(98 \%) .{ }^{1} \mathrm{H}-\mathrm{NMR}\left(\mathrm{CDCl}_{3}\right): \delta 2.63\left(2 \mathrm{H}, \mathrm{CH}_{2}^{\beta}\right), 3.81$ $\left(1 \mathrm{H}, \mathrm{CH}^{\alpha}\right), 7.12-7.38(15 \mathrm{H}, \mathrm{Trt}) .{ }^{13} \mathrm{C}-\mathrm{NMR}\left(\mathrm{CDCl}_{3}\right): \delta 36.10$ $\left(\mathrm{CH}_{2}^{\beta}\right), 67.05,68.96\left(\mathrm{Ph}_{3}, \mathrm{CH}^{\alpha}\right), 126.92,127.16,128.06,129.54$, 144.32 (phenyl), 176.40 (COOH). MS: 275.2 [TrtS $^{-}, 362.9$ [M $\mathrm{H}]^{-}$(Fig. S2 $\dagger$ ).

\section{Peptide synthesis}

The Cys-containing peptide fragments $\left[\mathrm{Cys}^{22}\right] \mathrm{BM} 2(22-35)$ (5) and $\left[\mathrm{Cys}^{22}\right] \mathrm{BM} 2(22-51)(\mathbf{1 1})$ were synthesized on an automated peptide synthesizer (Liberty, CEM) according to a standard Fmoc-protocol on AmphiSpheres RAM resin $\left(0.37 \mathrm{mmol} \mathrm{g}^{-1}\right.$ loading size). The coupling reactions (15 min, double coupling) were performed using Fmoc-amino acids (4 equiv.), activated with 1-[bis(dimethylamino)methylene]-1 $H$-1,2,3-triazolo[4,5-b] pyridinium 3-oxide hexafluorophosphate (HATU, 3.9 equiv.) and $N$-ethyl- $N$-(propan-2-yl)propan-2-amine (DIEA, 8 equiv.) in $\mathrm{N}, \mathrm{N}$-dimethylformamide (DMF) under microwave irradiation $\left(50{ }^{\circ} \mathrm{C}, 35 \mathrm{~W}\right)$. Fmoc-deprotection was achieved by treating the peptide-resin with $20 \%$ piperidine in DMF under microwave irradiation $\left(50{ }^{\circ} \mathrm{C}, 35 \mathrm{~W}\right)$, twice. All the deprotection and coupling steps were followed by intensive washing using DMF and dichloromethane (DCM).

The Hmp-containing model peptides (1-4) were synthesized manually on the resin. For the extended Hmp-containing peptides (8-10): the solubilizing tag $\left(\mathrm{Lys}_{5}, \mathrm{ADO}_{2}\right)$, spacer (ADO), Hmp unit and the first two amino acids of the respective peptide fragment were coupled manually to the resin. The following amino acids were coupled (30 min, double coupling) using an automated peptide synthesizer (Liberty, CEM) applying identical conditions as those for peptides $\mathbf{5}$ and $\mathbf{1 1 .}$ The $S$-acetamidomethyl (Acm) group was used as a side chain protection group for Cys11. For the peptides 8-10, Fmoc-groups were removed with $20 \%$ 2-methylpiperidine (v/v) in DMF.

The amino acid Leu21 (Ile21) was coupled to the preceding Hmp-unit as described by Liu et al. ${ }^{51}$ Accordingly, the resin was re-swollen in dry oxolane (THF) and treated twice (double coupling) with a $0.2 \mathrm{M}$ mixture of the amino acid (4 equiv.), triphenylphosphine (3.9 equiv.) and diethyl azodicarboxylate ( $40 \mathrm{wt} \%$ in toluene, 3.9 equiv.) for $2 \mathrm{~h}$. Afterwards, the resin was washed intensively with THF.

Peptide cleavage and deprotection was accomplished in a mixture of $90 \%$ TFA, $5 \%$ water, $2.5 \%$ TIPS and $2.5 \%$ anisole for $3 \mathrm{~h}$ at room temperature. The crude peptides were precipitated in cold diethyl ether, centrifuged, and washed with diethyl ether.

\section{Peptide purification}

The peptides 1-11 were purified by preparative RP-HPLC using a C18 column (MultoKrom 100-5, $250 \times 20 \mathrm{~mm}, 100 \AA$ pore diameter, and $5.0 \mu \mathrm{m}$ particle size). The peptides 7-11, 12a, 12b and 12c were purified using a C4 column (MultoHigh Bio 300-5, $250 \times 20 \mathrm{~mm}, 300 \AA$ pore diameter, and $5.0 \mu \mathrm{m}$ particle size). Water (containing $0.1 \%$ TFA, eluent A) and acetonitrile (containing $0.1 \%$ TFA, eluent B) were used as the HPLC eluent system. The RP-HPLC, MALDI-TOF MS and ESI-MS data of peptides 1-11, 12a, 12b and 12c are summarized in Table S2. $\dagger$

\section{Native chemical ligation}

The ligation experiments were performed in the ligation buffers (Buffer A, B and C, see Table S6 $\dagger$ ) at a $1: 1.5(\mathrm{n} / \mathrm{n})$ ratio of the thioester-forming peptide (1-4, 8-10, $1 \mathrm{mM})$ and Cys-peptide (5, $11,1.5 \mathrm{mM}$ ). The ligation reaction was initiated by adjusting the $\mathrm{pH}$ of the ligation buffer to $\mathrm{pH} 7.0$ or $\mathrm{pH} 7.5$ with $\mathrm{NaOH}(1 \mathrm{M})$ depending on the used buffer (ESI Table S6 $\dagger$ ). All ligation experiments were performed under an $\mathrm{N}_{2}$ atmosphere.

The reaction progress was monitored by analytical RP-HPLC employing a C18 $(150 \times 4 \mathrm{~mm}, 100 \AA$ A pore diameter, and $3.0 \mu \mathrm{m}$ particle size $)$ or C4 column $(100 \times 4 \mathrm{~mm}, 120 \AA$ pore diameter, and $2.1 \mu \mathrm{m}$ particle size) with linear gradients of $15-45 \%$ eluent $\mathrm{B}$ over $30 \mathrm{~min}$ (for the ligation mixtures $1+5,2+5$, and $3+5$ ), $20-40 \%$ eluent $B$ over $30 \mathrm{~min}$ (for the ligation mixture $4+5$ ) and $10-20 \%$ eluent B over 5 min followed by $20-70 \%$ eluent B over $20 \mathrm{~min}$ (for the ligation mixtures $\mathbf{8}+\mathbf{1 1}, \mathbf{9}+\mathbf{1 1}$, and $\mathbf{1 0}+\mathbf{1 1}$ ).

\section{Desulfurization of $\left[\mathrm{Cys}^{11}(\mathrm{Acm}), \mathrm{Cys}^{22}\right] \mathrm{BM} 2(1-51)$}

A $0.5 \mathrm{M}$ tris(2-carboxyethyl)phosphine (TCEP) $\mathrm{HCl}$ solution in $6 \mathrm{M}$ guanidinium hydrochloride ( $\mathrm{GdnHCl}) / 0.2 \mathrm{M}$ disodium phosphate buffer was prepared. The $\mathrm{pH}$ of this solution was adjusted to 6.5 and reduced glutathione (GSH, $125 \mu \mathrm{L}$ of a $160 \mathrm{mM}$ solution in water) was added. The reaction was performed under a nitrogen atmosphere. $1.2 \mathrm{mg}$ of the peptide [Cys $\left.{ }^{11}(\mathrm{Acm}), \mathrm{Cys}^{22}\right] \mathrm{BM} 2(1-51)$ was dissolved in $2 \mathrm{~mL}$ HFIP and added to the reaction solution. Afterwards, $200 \mu \mathrm{L}$ of a VA-044 solution (300 $\mathrm{mM}$ in water) was added and left to react for $6 \mathrm{~h}$. The reaction progress was monitored by analytical RPHPLC (C4 column $125 \times 4 \mathrm{~mm}, 300 \AA$ A pore diameter, and 5.0 $\mu \mathrm{m}$ particle size) with a linear gradient of $45-70 \%$ eluent $\mathrm{B}$ over

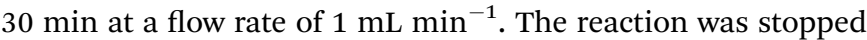
by transferring the lower layer into the 4 -fold volume of $0.1 \%$ trifluoroacetic acid (TFA). The solution was freeze-dried and the peptide was isolated by preparative RP-HPLC using a C4 column (MultoHigh Bio 300-5, $250 \times 20 \mathrm{~mm}, 300 \AA$ pore diameter, and $5.0 \mu \mathrm{m}$ particle size) with a linear gradient of $40-80 \%$ eluent B 
over $50 \mathrm{~min}$ at a flow rate of $10 \mathrm{~mL} \min ^{-1}$. Yield: $1.09 \mathrm{mg}$ $\left[\mathrm{Cys}^{11}(\mathrm{Acm})\right] \mathrm{BM} 2(1-51)(91 \%)$.

\section{Acm-group deprotection of $\left[{ }^{11} \mathrm{Cys}(\mathrm{Acm})\right] \mathrm{BM} 2(1-51)$ with silver trifluoromethanesulfonate}

$0.6 \mathrm{mg}$ (1 equiv.) of $\left[\mathrm{Cys}^{11}(\mathrm{Acm})\right] \mathrm{BM} 2(1-51)$ was dissolved in a solution of $7.7 \mathrm{mg}$ silver trifluoromethanesulfonate $(0.03 \mathrm{mM}$, 300 equiv.) $/ 1.6 \mu \mathrm{L}$ anisole ( $15 \mathrm{nM}, 150$ equiv.) $/ 1 \mathrm{~mL}$ TFA, and left to react for $90 \mathrm{~min}$ at $4{ }^{\circ} \mathrm{C}$ under a nitrogen atmosphere. The reaction progress was monitored by analytical RP-HPLC employing a C4 column $(125 \times 4 \mathrm{~mm}, 300 \AA$ pore diameter, and $5.0 \mu \mathrm{m}$ particle size) with a linear gradient of $45-70 \%$ eluent

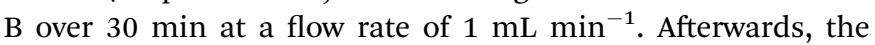
reaction was stopped by adding a two-fold excess of a DTT solution $(6 \mathrm{M})$ in acetic acid/water $(1: 1)$. The solution was agitated for $2 \mathrm{~h}$ at $20{ }^{\circ} \mathrm{C}$. Finally, the Ag-DTT supernatant was centrifuged, and the peptide was purified by preparative RPHPLC using a C4 column (MultoHigh Bio 300-5, $250 \times 20$ $\mathrm{mm}, 300$ A pore diameter, and $5.0 \mu \mathrm{m}$ particle size) with a linear gradient of $40-99 \%$ eluent B over $80 \mathrm{~min}$ at a flow rate of 10 $\mathrm{mL} \min ^{-1}$. Yield: $65 \%$ via HPLC.

\section{Circular dichroism (CD) spectroscopy}

CD spectra were recorded at $190-260 \mathrm{~nm}(0.1 \mathrm{~cm}$ path-length cuvette, $\left.20{ }^{\circ} \mathrm{C}\right) 30 \mathrm{~min}$ after the peptide $\left(0.1 \mathrm{mg} \mathrm{mL}{ }^{-1}\right)$ was dissolved in TFE, buffer (0.2 M, $\left.\mathrm{Na}_{2} \mathrm{HPO}_{4}, \mathrm{pH} 7.0\right)$, buffer/2,2,2trifluorethanol (TFE, $2: 1$ ) and buffer/1,1,1,3,3,3-hexafluor-2propanol (HFIP, 2:1). Lipid membrane samples were prepared in a degassed $10 \mathrm{mM} \mathrm{Na} \mathrm{HPO}_{4}$ buffer ( $\mathrm{pH}$ 7.5) containing $0.5 \mathrm{mg} \mathrm{mL} \mathrm{m}^{-1}$ 1-Palmitoyl-2-oleoylphosphatidylcholine (POPC). Therefore, 15 eq. of POPC and 1 eq. of peptide were dissolved together in a small amount of TFE. The solvent was carefully removed using nitrogen gas, and the lipid/peptide mixture was dried under vacuum overnight. The dried residue was suspended in a degassed $\mathrm{Na}_{2} \mathrm{HPO}_{4}$ buffer $(10 \mathrm{mM})$ and was shaken for $2 \mathrm{~h}$ at room temperature under an argon atmosphere. The sample was subjected to three freeze/thaw cycles and was finally extruded using a $1 \mu \mathrm{m}$ polycarbonate membrane. Spectral deconvolution was performed using CDNN (Circular Dichroism analysis using Neural Networks) software.

\section{Conflicts of interest}

There are no conflicts to declare.

\section{Acknowledgements}

Financial support for this project from the Liebig Fellowship of the Fonds der Chemischen Industrie im Verband der Chemischen Industrie e.V., LOEWE project iNAPO funded by the Ministry of Higher education, Research and the Arts (HMWK) of the Hessen state and Athene Young Investigator Program (TU Darmstadt) is gratefully acknowledged (A. A. T). The MS-facility team of the Chemistry Department especially C. Rudolph and A. Schießer (TU Darmstadt) for measurements of the ESI spectra are acknowledged. We are thankful to Fraunhofer LBF,
Darmstadt, Dr Frank Malz, for providing access to a MALDI spectrometer. We thank Prof. C. M. Thiele (TU Darmstadt) for the use of a peptide synthesizer. The CD spectra of BM2(1-33) are kindly provided by Prof. Mei Hong (MIT, Boston, USA).

\section{References}

1 Y. Arinaminpathy, E. Khurana, D. M. Engelman and M. B. Gerstein, Drug Discov. Today, 2009, 14, 1130-1135.

2 J. P. Overington, B. Al-Lazikani and A. L. Hopkins, Nat. Rev. Drug Discov., 2006, 5, 993-996.

3 W. A. Catterall, Neuron, 2000, 26, 13-25.

4 N. Eijkelkamp, J. E. Linley, M. D. Baker, M. S. Minett, R. Cregg, R. Werdehausen, F. Rugiero and J. N. Wood, Brain, 2012, 135, 2585-2612.

5 M. de Lera Ruiz and R. L. Kraus, J. Med. Chem., 2015, 58, 7093-7118.

6 F. Miceli, M. V. Soldovieri, P. Ambrosino, M. De Maria, L. Manocchio, A. Medoro and M. Taglialatela, Front. Cell. Neurosci., 2015, 9, 259.

7 T. Sato, Biopolymers, 2016, 106, 613-621.

8 X. Hou and L. Jiang, ACS Nano, 2009, 3, 3339-3342.

9 S. B. Kent, Chem. Soc. Rev., 2009, 38, 338-351.

10 D. Olschewski and C. F. Becker, Mol. BioSyst., 2008, 4, 733740.

11 M. Chen, P. Heimer and D. Imhof, Amino Acids, 2015, 47, 1283-1299.

12 G. G. Kochendoerfer, D. Salom, J. D. Lear, R. Wilk-Orescan, S. B. H. Kent and W. F. DeGrado, Biochemistry, 1999, 38, 11905-11913.

13 J. S. Zheng, S. Tang, Y. K. Qi, Z. P. Wang and L. Liu, Nat. Protoc., 2013, 8, 2483-2495.

14 J.-S. Zheng, S. Tang, Y.-C. Huang and L. Liu, Acc. Chem. Res., 2013, 46, 2475-2484.

15 M. Paradis-Bas, J. Tulla-Puche and F. Albericio, Chem. Soc. Rev., 2016, 45, 631-654.

16 C. Zuo, S. Tang and J. S. Zheng, J. Pept. Sci., 2015, 21, 540549.

17 L. E. Fisher and D. M. Engelman, Anal. Biochem., 2001, 293, 102-108.

18 K. J. Glover, P. M. Martini, R. R. Vold and E. A. Komives, Anal. Biochem., 1999, 272, 270-274.

19 T. Wohr, F. Wahl, A. Nefzi, B. Rohwedder, T. Sato, X. C. Sun and M. Mutter, J. Am. Chem. Soc., 1996, 118, 9218-9227.

20 I. Coin, M. Beyermann and M. Bienert, Nat. Protoc., 2007, 2, 3247-3256.

21 Y. Sohma, Y. Hayashi, M. Skwarczynski, Y. Hamada, M. Sasaki, T. Kimura and Y. Kiso, Biopolymers, 2004, 76, 344-356.

22 S. O. Smith, R. Jonas, M. Braiman and B. J. Bormann, Biochemistry, 1994, 33, 6334-6341.

23 S. D. Cady, J. Wang, Y. B. Wu, W. F. DeGrado and M. Hong, J. Am. Chem. Soc., 2011, 133, 4274-4284.

24 T. Sato, T. Kawakami, K. Akaji, H. Konishi, K. Mochizuki, T. Fujiwara, H. Akutsu and S. Aimoto, J. Pept. Sci., 2002, 8, 172-180.

25 S. C. Li and C. M. Deber, FEBS Lett., 1992, 311, 217-220. 
26 J. S. Zheng, M. Yu, Y. K. Qi, S. Tang, F. Shen, Z. P. Wang, L. Xiao, L. Zhang, C. L. Tian and L. Liu, J. Am. Chem. Soc., 2014, 136, 3695-3704.

27 S. Ficht, R. J. Payne, R. T. Guy and C. H. Wong, Chemistry, 2008, 14, 3620-3629.

28 S. K. Maity, G. Mann, M. Jbara, S. Laps, G. Kamnesky and A. Brik, Org. Lett., 2016, 18, 3026-3029.

29 J.-S. Zheng, Y. He, C. Zuo, X.-Y. Cai, S. Tang, Z. A. Wang, L.-H. Zhang, C.-L. Tian and L. Liu, J. Am. Chem. Soc., 2016, 138, 3553-3561.

30 S. Bondalapati, E. Eid, S. M. Mali, C. Wolberger and A. Brik, Chem. Sci., 2017, 8, 4027-4034.

31 M. T. Jacobsen, M. E. Petersen, X. Ye, M. Galibert, G. H. Lorimer, V. Aucagne and M. S. Kay, J. Am. Chem. Soc., 2016, 138, 11775-11782.

32 C. Zuo, S. Tang, Y.-Y. Si, Z. A. Wang, C.-L. Tian and J.-S. Zheng, Org. Biomol. Chem., 2016, 14, 5012-5018.

33 E. C. Johnson and S. B. Kent, Tetrahedron Lett., 2007, 48, 1795-1799.

34 M. Paradis-Bas, J. Tulla-Puche and F. Albericio, Org. Lett., 2015, 17, 294-297.

35 D. R. Englebretsen and G. T. Robillard, Tetrahedron, 1999, 55, 6623-6634.

36 N. K. Chu, W. Shabbir, E. Bove-Fenderson, C. Araman, R. Lemmens-Gruber, D. A. Harris and C. F. Becker, J. Biol. Chem., 2014, 289, 30144-30160.

37 J.-X. Wang, G.-M. Fang, Y. He, D.-L. Qu, M. Yu, Z.-Y. Hong and L. Liu, Angew. Chem., Int. Ed., 2015, 54, 2194-2198.

38 T. Sato, Y. Saito and S. Aimoto, J. Pept. Sci., 2005, 11, 410416.

39 C. T. Choma, G. T. Robillard and D. R. Englebretsen, Tetrahedron Lett., 1998, 39, 2417-2420.

40 S. Tang, C. Zuo, D. L. Huang, X. Y. Cai, L. H. Zhang, C. L. Tian, J. S. Zheng and L. Liu, Nat. Protoc., 2017, 12, 2554-2569.

41 S. Chemuru, R. Kodali and R. Wetzel, Pept. Sci., 2014, 102, 206-221.

42 D. R. Englebretsen and P. F. Alewood, Tetrahedron Lett., 1996, 37, 8431-8434.

43 R. Raz, F. Burlina, M. Ismail, J. Downward, J. Li, S. J. Smerdon, M. Quibell, P. D. White and J. Offer, Angew. Chem., Int. Ed., 2016, 55, 13174-13179.

44 M. Dittman and M. Engelhard, in Chemical Ligation, John Wiley \& Sons, Inc., 2017, pp. 269-284, DOI: 10.1002/ 9781119044116.ch7.

45 G.-M. Fang, Y.-M. Li, F. Shen, Y.-C. Huang, J.-B. Li, Y. Lin, H.-K. Cui and L. Liu, Angew. Chem., Int. Ed., 2011, 50, 7645-7649.

46 G. Chen, J. D. Warren, J. Chen, B. Wu, Q. Wan and S. J. Danishefsky, J. Am. Chem. Soc., 2006, 128, 7460-7462.

47 J. D. Warren, J. S. Miller, S. J. Keding and S. J. Danishefsky, J. Am. Chem. Soc., 2004, 126, 6576-6578.

48 J.-S. Zheng, W.-X. Xi, F.-L. Wang, J. Li and Q.-X. Guo, Tetrahedron Lett., 2011, 52, 2655-2660.

49 P. Botti, M. Villain, S. Manganiello and H. Gaertner, Org. Lett., 2004, 6, 4861-4864.
50 J.-S. Zheng, H.-N. Chang, J. Shi and L. Liu, Sci. China: Chem., 2012, 55, 64-69.

51 F. Liu and J. P. Mayer, J. Org. Chem., 2013, 78, 9848-9856.

52 C. Ma, C. S. Soto, Y. Ohigashi, A. Taylor, V. Bournas,

B. Glawe, M. K. Udo, W. F. Degrado, R. A. Lamb and

L. H. Pinto, J. Biol. Chem., 2008, 283, 15921-15931.

53 R. M. Pielak and J. J. Chou, Biochim. Biophys. Acta, 2011, 1808, 522-529.

54 J. Wang, R. M. Pielak, M. A. McClintock and J. J. Chou, Nat. Struct. Mol. Biol., 2009, 16, 1267-1271.

55 J. K. Williams, D. Tietze, M. Lee, J. Wang and M. Hong, J. Am. Chem. Soc., 2016, 138, 8143-8155.

56 K. Wisniewski, Org. Prep. Proced. Int., 1999, 31, 211-214.

57 S. Peigneur, M. Paolini-Bertrand, H. Gaertner, D. Biass, A. Violette, R. Stocklin, P. Favreau, J. Tytgat and O. Hartley, J. Biol. Chem., 2014, 289, 35341-35350.

58 M. A. Hossain, A. Belgi, F. Lin, S. Zhang, F. Shabanpoor, L. Chan, C. Belyea, H.-T. Truong, A. R. Blair and S. Andrikopoulos, Bioconjugate Chem., 2009, 20, 1390-1396.

59 R. Fischer, T. Waizenegger, K. Köhler and R. Brock, Biochim. Biophys. Acta, 2002, 1564, 365-374.

60 T. Y. But and P. H. Toy, Chem.-Asian J., 2007, 2, 1340-1355. 61 P. Thapa, R.-Y. Zhang, V. Menon and J.-P. Bingham, Molecules, 2014, 19, 14461.

62 B. Kwon, D. Tietze, P. B. White, S. Y. Liao and M. Hong, Protein Sci., 2015, 24, 1087-1099.

63 M. D'Ischia, G. Prota, R. C. Rotteveel and W. Westerhof, Synth. Commun., 1987, 17, 1577-1585.

64 A. Furstner, D. De Souza, L. Turet, M. D. Fenster, L. ParraRapado, C. Wirtz, R. Mynott and C. W. Lehmann, Chemistry, 2007, 13, 115-134.

65 L. Z. Yan and P. E. Dawson, J. Am. Chem. Soc., 2001, 123, 526533.

66 Q. Wan and S. J. Danishefsky, Angew. Chem., Int. Ed., 2007, 46, 9248-9252.

67 S. Zhang, F. Lin, M. A. Hossain, F. Shabanpoor, G. W. Tregear and J. D. Wade, Int. J. Pept. Res. Ther., 2008, 14, 301-305.

68 I. Friligou, E. Papadimitriou, D. Gatos, J. Matsoukas and T. Tselios, Amino Acids, 2011, 40, 1431-1440.

69 S. Andrew, J. Chem. Soc., Perkin Trans. 1, 1993, 19471952.

70 N. Fujii, A. Otaka, T. Watanabe, A. Okamachi, H. Tamamura, H. Yajima, Y. Inagaki, M. Nomizu and K. Asano, Chem. Commun., 1989, 283-284.

71 P. M. Moyle, C. Olive, M. F. Good and I. Toth, J. Pept. Sci., 2006, 12, 800-807.

72 H. Tamamura, R. Ikoma, M. Niwa, S. Funakoshi, T. Murakami and N. Fujii, Chem. Pharm. Bull., 1993, 41, 978-980.

73 M. Yoshida, T. Tatsumi, Y. Fujiwara, S. Iinuma, T. Kimura, K. Akaji and Y. Kiso, Chem. Pharm. Bull., 1990, 38, 15511557.

74 B. L. Pentelute and S. B. H. Kent, Org. Lett., 2007, 9, 687-690.

75 J. V. Castell and A. Tun-Kyi, Helv. Chim. Acta, 1979, 62, 25072510. 
76 K. M. Harris, S. Flemer and R. J. Hondal, J. Pept. Sci., 2007, 13, 81-93.

77 S. Marie, J. Emma, E. L. Ruggles and R. J. Hondal, J. Pept. Sci., 2016, 22, 571-576.
78 A. L. Schroll, R. J. Hondal and S. Flemer, J. Pept. Sci., 2012, 18, 1-9.

79 M. Yoshida, K. Akaji, T. Tatsumi, S. Iinuma, Y. Fujiwara, T. Kimura and Y. Kiso, Chem. Pharm. Bull., 1990, 38, 273275. 